ISSN 1896-8147

DOI: http://dx.doi.org/10.21784/EiZ.2016.018

MAREK SŁUPCZEWSKI

Uniwersytet Mikołaja Kopernika w Toruniu

\title{
Outsourcing pracowniczy jako ryzykowny sposób zarządzania kadrami - prawna i ekonomiczna odpowiedzialność płatnika składek na ubezpieczenia społeczne
}

\section{Employee outsourcing as a risky way of human resources management - legal and economic responsibility of the payer of social security contributions}

\section{Streszczenie:}

W dzisiejszych czasach wszelkie zdarzenia gospodarcze są ze sobą powiązane i wywołują daleko idące skutki w różnych dziedzinach prawa. Podobnie jest w przypadku outsourcingu pracowniczego, stosunkowo młodej, lecz mogącej przysporzyć wielu problemów uczciwym przedsiębiorcom instytucji. Przekazanie pracowników na mocy porozumienia które stanowi istotny element badanego zagadnienia wiąże się nie tylko z oddaniem statusu pracodawcy, lecz także funkcji płatnika składek na ubezpieczenia społeczne. W niniejszym artykule zaprezentowane zostaną podstawowe założenia, cechy i skutki outsourcingu pracowniczego jako sposobu zarządzania organizacją, ze szczególnym uwzględnieniem negatywnych konsekwencji wadli- 
wego porozumienia. Konsekwencji, które są rezultatem prób podjętych w celu unowocześnienia procesu zarządzana przedsiębiorstwem oraz chęci zwiększenia zakresu działania na rynku.

\section{Summary}

Nowadays all economic events are interrelated and cause far-reaching consequences in various areas of law. Similarly, in the case of outsourcing of staff, relatively young, but likely to cause many problems to honest entrepreneurs, institution. The transfer of workers under the agreement, which is an important element of the problem is not only connected with transferring status of the employer, but also the function of a payer of social insurance contributions. In this article we will present the basic assumptions, characteristics and effects of outsourcing employees as a strategy of business management, with particular emphasis on the negative consequences of a defective agreement. The consequences which are the result of attempts to modernize the process of management of the company and the desire of increasing the range of activities on the market.

Słowa kluczowe: outsourcing pracowniczy, przekazanie pracowników, składki na ubezpieczenia społeczne, płatnik składek na ubezpieczenia społeczne, przejście zakładu pracy.

Key words: employee outsourcing, transfer of employees, social security contributions, payer of social security contributions, transfer of employment.

\section{Wprowadzenie}

Outsourcing pracowniczy od pewnego czasu stanowi atrakcyjną ofertę dla przedsiębiorców. Pozwala na optymalizację zarządzania organizacją, ograniczenie kosztów prowadzonej działalności poprzez rezygnację z wydatków na utrzymywanie stałego działu zarządzania zasobami ludzkimi, zwiększenie jakości świadczonych usług, poprawę czasu realizacji zadań, a także koncentrację na rozwoju w strategicznych dziedzinach ${ }^{5}$.

5 K. Kalinowska, Outsourcing jako metoda zarzqdzania przedsiębiorstwem, ZESZYTY NAUKOWE POLITYKI EUROPEJSKIE, FINANSE I MARKETING, Nr 3 (52) 2010, s. 262 
Zwiększenie efektywności we wskazanych powyżej dziedzinach bezpośrednio przekłada się na poprawę funkcjonowania przedsiębiorstwa oraz jego rachunku ekonomicznego. Niejednokrotnie jednak chęć zwiększenia konkurencyjności i konfrontacji z większymi podmiotami poprzez wybór outsourcingu jako metody zarządzania skutkuje ujemnymi konsekwencjami. Dzieje się tak w przypadkach, gdy dojdzie do nawiązania przez przedsiębiorcę współpracy z nierzetelnym kontrahentem z zakresu usług pracowniczych. Konsekwencje ekonomiczne w praktyce gospodarczej spotykają nieświadome podmioty i zaczynają się od spowolnienia rozwoju, kończąc na konieczności likwidacji działalności.

Podmiotem prowadzącym działalność gospodarczą zainteresowanym outsourcingiem pracowniczym jest $\mathrm{z}$ reguły pracodawca zatrudniający przynajmniej kilkunastu pracowników. Zainteresowanie przekazaniem działu zarządzania zasobami ludzkimi przez większe podmioty wynika z podstawowej kwestii, jaką jest efekt skali. Wiadomym jest bowiem, że nawet niewielka oszczędność jednostkowa przy uwzględnieniu niejednokrotnie znacznej ilości zatrudnionych może skutkować zauważalnymi oszczędnościami. Oszczędnościami, które wiążą się z jeszcze jedną korzyścią - „ograniczeniem obowiązków pracodawcy”. Zwrócić jednak należy uwagę na określenie - ograniczeniem, nie zwolnieniem. W tym konkretnym przypadku, właściwszym byłoby słowo „zastępuje”, „wyręcza”. Znaczenia tego określenia wzrasta, gdy podmiot świadczący usługę outsourcingu traci płynność finansową i przestaje wypełniać swoje zobowiązania płatnicze, lub też, gdy okazuje się, że podmiot ten od początku pozostawał w złym zamiarze, który objawił się brakiem odprowadzania składek lub też zaliczek na podatek dochodowy od osób fizycznych i w odpowiednim momencie zaprzestał prowadzenia działalności. Praktyka wskazuje, że opisany koniec działalności takiego podmiotu oznacza początek problemów finansowych przedsiębiorcy nabywającego usługę outsourcingu. Niejednokrotnie zdarzało się, że w takiej sytuacji organy kwestionowały ważność porozumienia o przejęciu pracowników zawartego między tymi podmiotami i próbowały wykazać, że nie doszło do przejścia 
zakładu pracy w rozumieniu art. 23^1 Kodeksu pracy z dnia 26 czerwca 1974 r.6. Zagadnienie to doczekało się licznego orzecznictwa, którego tezy stanowią doskonały arsenał argumentów zarówno dla organów, jak i dla płatników/podmiotów próbujących wykazać, że płatnikami nie są. Rzeczywistym zaś skutkiem zakwestionowania przez właściwe organy podstawy porozumienia są decyzje określające zobowiązania w podatku od towarów i usług (poprzez uznanie, że faktury nie dokumentowały rzeczywistych zdarzeń gospodarczych, art. 88 ust 3a pkt 4 lit a ustawy z dnia 11 marca 2004 r. o podatku od towarów i usług)7 ${ }^{7}$. Jednocześnie następuje próba przypisania odpowiedzialności $\mathrm{z}$ tytułu niewpłacania zaliczek na podatek dochodowy od osób fizycznych - zaliczek, które pracodawca, jako płatnik powinien był regularnie odprowadzać na rachunek urzędu skarbowego. 0 ile opłacone zaległości z tytułu niepobranych i niewpłaconych zaliczek na podatek dochodowy możliwe są do odzyskania przez pracodawcę na drodze postępowania cywilnego (po stronie pracodawcy powstaje roszczenie regresowe wobec pracownika, jeśli uiścił podatek w należytej wysokości, na przykład na skutek orzeczenia w przeciwnym razie doszłoby do bezpodstawnego wzbogacenia pracownika ${ }^{8}$ ), to problem pojawia się także przy należnościach składkowych za obowiązkowe ubezpieczenia społeczne (emerytalne itd.). Powstanie wysokich zaległości podatkowych często skutkuje wydaniem decyzji zabezpieczającej na podstawie art. 33 ustawy z dnia 29 sierpnia $1997 \mathrm{r}$. ordynacja podatkowa ${ }^{9}$, a tym samym zajęciu, najczęściej rachunków bankowych. Perturbacje z organami utrudniają zdobycie finansowania w drodze kredytowania i przedsiębiorca zmuszony jest zamknąć zakład już na etapie poprzedzającym wydanie ostatecznej decyzji wymiarowej, nie doczekując nawet postępowania egzekucyjnego. W przedmiotowym artykule zbadane zostaną podstawowe zagadnienia dotyczące odpowie-

\footnotetext{
6 tj. z dnia 8 września 2016 r. (Dz.U. z 2016 r. poz. 1666)

7 tj. z dnia 10 maja 2016 r. (Dz.U. z 2016 r. poz. 710)

8 Orzeczenie Naczelnego Sądu Administracyjnego z dnia 26 kwietnia 2000 o sygnaturze III SA $833 / 99$

${ }^{9}$ tj. z dnia 8 kwietnia 2015 r. (Dz.U. z 2015 r. poz. 613)
} 
dzialności i statusu płatnika składek na ubezpieczenia społeczne w związku $\mathrm{z}$ outsourcingiem pracowniczym.

W artykule wykorzystano metodę prawno-dogmatyczną celem zdekodowania norm prawnych, a także prawno-porównawczą oraz analityczną.

\section{Definicja outsourcingu}

Outsourcing składa się ze słów outside resource using i definiowany jest jako „wydzielenie ze struktury organizacyjnej przedsiębiorstwa macierzystego realizowanych przez nie funkcji i przekazanie ich do wykonania innym podmiotom gospodarczym" 10 . Generalizując zaś, jest to zyskująca popularność strategia zarządzania organizacją. W literaturze przedmiotu wskazuje się, że o ile historia outsourcingu jest długa, to praktyczne znaczenie zyskuje od mniej więcej 30 - 40 lat. Za prekursora uznaje się Henry'ego Forda. Pierwotnie outsourcing dotyczył procesów produkcyjnych, przedsiębiorstwa dokonywały fragmentacji procesów produkcyjnych i przekazywały wykonywanie półproduktów innym podmiotom. Skutkiem był wzrost fragmentacji produkcji oraz zacieśnienie powiązań między współdziałającymi podmiotami11. Procesom tym sprzyja dziś rozwój informatyzacji wszystkich dziedzin życia oraz postępująca globalizacja. Outsourcing jest pojmowany jako możliwość skupienia się przez przedsiębiorstwo na jego kluczowych kompetencjach, a także usprawnienie działalności i zwiększenie efektywności bez czynienia nakładów na inwestycje ${ }^{12}$. Wybór outsourcing jako strategii zarządzania traktuje się jako zmianę o charakterze strategicznym,

10 D. Ciesielska, M. Radło, Outsourcing w praktyce, autor definicji: M. Trocki, wydawnictwo Poltext, Warszawa 2011 r. s. 9

11 D. Ciesielska, M. Radło, Outsourcing..., s. 13,

12 D. Ciesielska, M. Radło, Outsourcing ..., s. 17, 
wpływa bezpośrednio na strukturę organizacyjną, warunki ekonomiczne i społeczne przedsiębiorstwa ${ }^{13}$.

\section{Definicja outsourcingu pracowniczego}

Na potrzeby niniejszego artykułu należy wyjaśnić pojęcie outsourcingu pracowniczego, który jest jedną z odmian właściwego outsourcingu.

Poszukując instytucji zbliżonej do outsourcingu pracowniczego, zjawisko to może wydawać się z pozoru podobne do multiplikacji horyzontalnej stosunku pracowniczego, która cechuje się tym, że po stronie zatrudniającej pojawia się kilka różnych podmiotów ${ }^{14}$. Podobieństwa mogą stać się wyraziste w sytuacji, gdy podmiot przejmujący pracowników zaprzestaje opłacania składek na ubezpieczenia społeczne, a organy kierują swą uwagę ku pierwotnemu pracodawcy. To co jednak odróżnia outsourcing pracowniczy od multiplikacji stosunku pracy jest brak defragmentacji stosunku pracy - zgodnie z wolą podmiotu wydzielającego zadanie, stosunek pracy jest jeden, ciągły, zmianie ulega jedynie strona tego stosunku (pracodawca). W przypadku multiplikacji, stosunki pracownicze są co najmniej dwa.

Kontynuując rozważania należy zastanowić się, czy outsourcingu pracowniczego nie należałoby zakwalifikować jako zatrudnienia u kontrahenta pracodawcy. Istotnego znaczenia nabierają zakazy konkurencji, w szczególności te obowiązujące przez pewien okres po ustaniu stosunku pracy15. Rozważania te są jednak płonne, z dwojakich przyczyn.

\footnotetext{
${ }^{13}$ E. Szczepankiewicz, Strategiczny wymiar outsourcingu i co-sourcingu jako narzędzia optymalizacji procesów wewnętrznych przedsiębiorstwa i budowania przewagi konkurencyjnej [w:] A. Antonowicz, P. Antonowicz (red.), Metody, techniki i narzędzia optymalizacji procesów gospodarczych, Wydział Zarządzania Uniwersytetu Gdańskiego Fundacja Rozwoju Uniwersytetu Gdańskiego, Sopot 2011 r., s. 113,

${ }^{14} \mathrm{~A}$. Kurzych, Multiplikacja podmiotów zatrudniających a stosunki ubezpieczenia społecznego [w:] Marzena Szabłowska - Juckiewicz, Monika Wałachowska, Jacek Wantoch- Rekowski (red.), Umowy cywilnoprawne w ubezpieczeniach społecznych, Warszawa 2015, s. 333 344 .

15 M. Raczkowski, Zatrudnienie pracownika u kontrahenta pracodawcy [w:] Marzena Szabłowska - Juckiewicz, Monika Wałachowska, Jacek Wantoch - Rekowski (red.), Umowy cywilnoprawne w ubezpieczeniach społecznych, Warszawa 2015, s. 362-273,
} 
W pierwszej bowiem kolejności zauważyć należy, że zdaniem pierwotnego pracodawcy, istotą stosunku łączącego go z podmiotem zatrudniającym dotychczasowych pracowników jest właśnie możliwość świadczenia przez nich usług na jego rzecz. Bez tego, upada podstawa łączącego ich stosunku. Organy natomiast nie będą miały możliwości zarzucenia tego typu naruszeń, gdyż ich zdaniem nie doszło do zmiany pracodawcy.

Outsourcing pracowniczy, ściślej zwany outsourcingiem kadrowo płacowym, dotyczy wykonywania zadań pomocniczych. Skutkuje oddaniem innemu przedsiębiorstwu realizacji zadań nie związanych bezpośrednio z podstawową działalnością firmy. „Outsourcing pracowniczy zyskuje na znaczeniu w ostatnich latach. Staje się niezwykle popularną formą optymalizacji zatrudnienia, a tym samym sposobem na redukcję kosztów prowadzenia przedsiębiorstwa. Outsourcing polega na zlecaniu pewnych obszarów działalności przedsiębiorstwa wyspecjalizowanym podmiotom zewnętrznym świadczącym usługi. Jest odpowiedzią na dynamikę funkcjonowania przedsiębiorstwa oraz sytuację na rynku pracy. To rozwiązanie szybkie i efektywne. Umożliwia pozyskanie pracowników z obcych źródeł bez ponoszenia kosztów rekrutacji, szkolenia pracowników oraz stałych kosztów związanych z zatrudnieniem personelu"16. Wskazać należy, że przedsiębiorcy są często kuszeni ograniczeniem kosztów zatrudniania pracowników, poprzez, przykładowo rabat w wysokości 50\% kosztów przez pierwsze lata trwania umowy ${ }^{17}$.

W praktyce polega na tym, że podmioty zawierają porozumienia, których przedmiotem jest przejęcie za wynagrodzeniem dokumentacji pracowniczej i płacowej. Następnie, podmiot przejmujący udostępnia macierzystemu pracodawcy pracowników, z reguły są to te same osoby, które wcześniej u niego pracowały (w rezultacie, zmiana pracodawcy nie

16. Basińska, Outsourcing pracowniczy optymalizuje zatrudnienie, „Prawo i podatki”, czerwiec 2015 r.,

http://www.wglex.pl/wp-content/uploads/2016/04/Outsourcing-pracowniczyoptymalizuje-zatrudnienie.pdf

${ }^{17 K o n t r a h e n c i ~ m o z ̇ l i w o s ́ c ́ ~ p r z y z n a n i a ~ r a b a t u ~ u z a s a d n i a j a ̨ ~ o t r z y m y w a n y m ~ d o f i n a n s o w a n i e m ~}$ na swoją działalność. 
powoduje większych zmian po stronie pracowników). Istotnym jest, że podmiot macierzysty często nie przekazuje wraz $\mathrm{z}$ pracownikami składników majątkowych. Pracownicy zachowują dotychczasowe warunki pracy, zgodnie z dyspozycją art. 23^1 Kodeksu pracy. Pomijając uwarunkowania umowne typowe dla konkretnych typów działalności, w większości przypadków pracodawca użytkownik opłaca fakturę wystawioną przez nowego pracodawcę. Warunkiem przejęcia zakładu pracy w rozumieniu art. $23^{\wedge} 1$ Kodeksu pracy, a więc tym samym wstąpienia nowego podmiotu w miejsce poprzedniego jako pracodawcy (także przejęcia funkcji płatnika), w ocenie Sądu Najwyższego jest konieczność przejęcia faktycznego władania częściami zadań, stanowiących placówkę zatrudnienia, a więc w zakresie pozwalającym na wykonywanie obowiązków pracowniczych. Nie musi to jednak polegać na formalnym nabyciu przedsiębiorstwa lub jego części. Nie zależy również od rodzaju czynności prawnej, na mocy której nastąpiło przekazanie ${ }^{18}$. Przykładowo w wyroku Sądu Apelacyjnego w Białymstoku ${ }^{19}$ skład orzekający wskazał, że z przejściem o którym mowa $\mathrm{w}$ art. $23^{\wedge} 1$ Kodeksu pracy mamy do czynienia również $\mathrm{w}$ przypadku przejęcia zadań (bez znaczenia może pozostawać fakt, czy przeniesiona została własność składników majątkowych). Jednakże, gdy funkcjonowanie podmiotu opiera się składnikach materialnych, nie jest wystarczające wyłącznie zadań (przykładem może być obsługa sklepów). W takich właśnie przypadkach organy kwestionują ważność porozumienia, a tym samym przekazanie funkcji płatnika, co skutkuje odpowiedzialnością pierwotnego pracodawcy.

\section{Pojęcie płatnika składek na ubezpieczenia społeczne}

W art. 3 ustawy z dnia 13 października 1998 r. o systemie ubezpieczeń społecznych ${ }^{20}$ (dalej: usus) wskazane zostały podmioty wykonujące zadania z zakresu ubezpieczeń społecznych. Są to odpowiednio: Zakład

\footnotetext{
18 Wyrok SN z 15 września 2006 r. o sygnaturze I PK 75/06

19 Wyrok wyroku Sądu Apelacyjnego w Białymstoku z dnia 20 maja o sygnaturze III AUa $30 / 14$,

20 tj. z dnia 7 czerwca 2016 r. (Dz.U. z 2016 r. poz. 963)
} 
Ubezpieczeń Społecznych, otwarte fundusze emerytalne oraz płatnicy składek. Jakkolwiek zbędnym jest wyjaśnianie oczywistych ról ZUS’u i funduszy emerytalnych, nie należy zapominać o filarach odpowiedzialnych za pobieranie i wpłacenie składek ubezpieczeniowych, a więc finansowanie całego systemu zabezpieczenia społecznego. W przepisie tym zostało również ukształtowane prawo płatnika do otrzymywania wynagrodzenia za wykonywanie zadań związanych z ustalaniem prawa do świadczeń i ich wysokości oraz wypłatą świadczeń $\mathrm{z}$ ubezpieczenia chorobowego. Kluczowym przepisem w kwestii ustalenia, kto jest płatnikiem składek na ubezpieczenia społeczne jest art. 4 pkt 2 usus, który wskazuje kilkadziesiąt podmiotów pełniących funkcję płatników. Ze względu na mnogość wskazanych $\mathrm{w}$ nim podmiotów, regulacja ta zyskuje miano dosyć kazuistycznej i szczegółowej. Jest to jednak przykład właściwego doregulowania bardzo istotnej kwestii, której należy nadać status zasadniczej. Z punktu widzenia przedmiotowego artykułu, kluczowa jest pierwsza definicja, dotycząca pracodawcy ${ }^{21}$. Zgodnie $\mathrm{z}$ brzmieniem tego przepisu, płatnikiem jest pracodawca w stosunku do pracowników i osób odbywających służbę zastępczą oraz jednostka organizacyjna lub osoba fizyczna pozostająca $\mathrm{z}$ inną osobą fizyczną $\mathrm{w}$ stosunku prawnym uzasadniającym objęcie tej osoby ubezpieczeniami społecznymi, $\mathrm{w}$ tym $\mathrm{z}$ tytułu przebywania na urlopie wychowawczym albo pobierania zasiłku macierzyńskiego, z wyłączeniem osób, którym zasiłek macierzyński wypłaca Zakład. Praktyka wskazuje, że w obrocie gospodarczym to właśnie pracodawca najczęściej pełni funkcję płatnika składek.

Analizując pojęcie płatnika, wspomnieć należy o stosunku ubezpieczony - płatnik. W doktrynie wskazuje się, że charakterystycznym jest, iż uprawnienia przysługują tylko ubezpieczonemu, podczas gdy płatnik, będący drugą stroną stosunku jest wyłącznie obciążony obowiązkami. Brakuje tym samym dwustronności praw i obowiązków 22.

21 art. 4 pkt 2 lit a usus

${ }^{22}$ K. Antonów, Sprawy z zakresu ubezpieczeń społecznych, pojęcie oraz właściwość postępowań przedsądowych i ochrony cywilnosądowej, Lex a Wolters Kluwers business, Warszawa 2011 r., s 80-81, 


\section{Obowiązki płatnika składek na ubezpieczenia społeczne}

Podstawowym zadaniem płatnika składek na ubezpieczenia społeczne jest obliczanie, potrącanie $\mathrm{z}$ dochodów ubezpieczonych oraz rozliczanie i opłacanie należnych składek za każdy miesiąc kalendarzowy (opłacenie poprzez przekazanie do ZUS i obciążenie rachunku płatnika). Dla celów porządkowych należy wskazać rodzaje składek, których dotyczy obowiązek: składki na ubezpieczenia społeczne (emerytalne, rentowe, wypadkowe, chorobowe), zdrowotne, Fundusz Emerytur Pomostowych, Fundusz Pracy, Fundusz Gwarantowanych Świadczeń Pracowniczych. Przy ustalaniu wysokości składek, płatnik powinien się kierować zasadami określonymi w poszczególnych ustawach ${ }^{23}$.

W tym miejscu należy zwrócić uwagę na zasadniczą cechę odróżniającą płatnika składek na ubezpieczenia społeczne od płatnika zaliczek na podatek dochodowy od osób fizycznych. Mianowicie, rola płatnika składek na ubezpieczenia społeczne nie ogranicza się do obliczania i potrącania należnych składek z przychodu ubezpieczonego i wpłacania ich do ZUS. Płatnik został bowiem zobowiązany ustawowo do współfinansowania składek ze swoich środków, natomiast w przypadku składki na ubezpieczenie wypadkowe finansuje składki całkowicie. Wskazuje się więc, że płatnik może występować w podwójnej roli - płatnika - ubezpieczonego, przykładowo w przypadku osoby prowadzącej pozarolniczą działalność gospodarczą 24 .

Posiadanie statusu płatnika rodzi również obowiązki podczas kontroli inspektorów ZUS. W doktrynie wskazuje się, że zostały one bezpośrednio skorelowane z uprawnieniami inspektorów ${ }^{25}$. Obowiązki te konstytuuje art. 88 usus. Do głównych zadań płatnika podczas kontroli należy udostępnianie

\footnotetext{
23 Przykładowo: usus, ustawa o świadczeniach opieki zdrowotnej finansowanych ze środków publicznych, ustawa o ochronie roszczeń pracowniczych $\mathrm{w}$ razie niewypłacalności pracodawcy

24 B. Gudowska J. Strusińska - Żukowska, Komentarz do ustawy o systemie ubezpieczeń społecznych, wyd. BECK, Warszawa 2014 r. s. $24-25$.

25 B. Gudowska J. Strusińska - Żukowska, Komentarz do ustawy o systemie.., s. 1013.
} 
wszelkich ksiąg, dokumentów i innych nośników informacji związanych z zakresem kontroli, które są przechowywane u płatnika oraz u osób trzecich $\mathrm{w}$ związku z powierzeniem tym osobom niektórych czynności na podstawie odrębnych umów. Przemyślanym rozwiązaniem wydaje się być zamieszczenie w przepisie adnotacji o konieczności udostępnienia ksiąg także w wypadku, gdy znajdują się one u osoby trzeciej. Przy czym określenie osoby trzeciej $\mathrm{w}$ postępowaniu składkowym zostało użyte z korzyścią dla organu. W przypadku bowiem zakwestionowania porozumienia o przekazaniu pracowników, „były” pracodawca będzie utrzymywał, że doszło do przejścia zakładu pracy na inny podmiot i że nie jest on płatnikiem, wobec czego nie dysponuje niezbędnymi dokumentami. Stosowna dokumentacja pracownicza została bowiem najprawdopodobniej przekazana po podpisaniu porozumienia nowemu pracodawcy. Płatnikiem natomiast jego zdaniem powinna być druga strona porozumienia. Dla organu, który kwestionuje podstawy nabycia statusu pracodawcy, a co za tym idzie płatnika, druga strona tej umowy pozostaje osobą trzecią. Rodzi to istotne komplikacje po stronie kontrolowanego płatnika składek, który zobowiązany jest pozyskać dokumentację dotyczącą pracowników zatrudnionych $\mathrm{w}$ innym podmiocie (pracodawca, będąc przekonanym o ważności porozumienia, przekazał wszystko innemu podmiotowi). Pozostałe zadania mają głównie charakter techniczny, ewidencyjny oraz informacyjny (przykładowo kontrolowany płatnik ma obowiązek sporządzić i wydać kopie dokumentów związanych z zakresem kontroli, udostępnić do oględzin składniki majątku, których badanie wchodzi w zakres kontroli, jeżeli zalegają $\mathrm{z}$ opłatą należności $\mathrm{z}$ tytułu składek; zapewnić niezbędne warunki do przeprowadzenia czynności kontrolnych; udzielać wyjaśnień kontrolującemu) ${ }^{26}$.

\section{Odpowiedzialność płatnika składek}

Od nieopłaconych w terminie składek należne są od płatnika składek odsetki za zwłokę ${ }^{27}$. W razie nieopłacenia składek lub opłacenia ich

26 B. Gudowska J. Strusińska - Żukowska, Komentarz do ustawy o systemie... s. 25,

${ }^{27}$ Art. 23 ust 1 usus 
w zaniżonej wysokości, Zakład może wymierzyć płatnikowi dodatkową opłatę do wysokości $100 \%$ nieopłaconych składek ${ }^{28}$. Ponadto, jak wynika z ustawy o Systemie ubezpieczeń społecznych: „Kto, jako płatnik składek albo osoba obowiązana do działania w imieniu płatnika nie dopełnia obowiązku opłacania składek na ubezpieczenia społeczne w przewidzianym przepisami terminie podlega karze grzywny do 5000 złotych"29. Kolejne artykuły wspomnianej ustawy tworzą możliwość ściągnięcia składek w trybie egzekucji administracyjnej lub sądowej ${ }^{30}$. Możliwości egzekwowania należności wzmacnia uregulowanie stanowiące, że wystawione przez Zakład dokumenty stwierdzające istnienie należności z tytułu składek oraz jej wysokość mogą stanowić podstawę wpisu hipoteki do księgi wieczystej nieruchomości stanowiącej własność zobowiązanego ${ }^{31}$. Zauważalnym więc jest, że organy posiadają typowe dla innych postępowań możliwości dochodzenia należnych składek. Odpowiedzialność płatnika składek aktualizuje się gdy organ uzna, że umowa mająca na celu przekazanie zakładu była nieważna. Gdy tak się dzieje, podmiot przejmujący zazwyczaj i tak jest już niewypłacalny.

W kwestii charakteru odpowiedzialności płatnika, należy przywołać stanowisko K. Antonów: „nieterminowe spełnienie świadczeń odnosi skutek w postaci naliczenia odsetek za zwłokę na zasadach i w wysokości określonych $\mathrm{w}$ ordynacji podatkowej $\mathrm{w}$ każdym przypadku opłacania składek z naruszeniem terminów (...), tzn. niezależnie od (nie)zawinionego postępowania płatnika, z zastrzeżeniem, że odsetki nie należą się ubezpieczonemu, lecz ustawowemu reprezentantowi jego interesów relacji ZUS płatnik. Przyjęta konstrukcja odpowiedzialności płatnika jest zbliżona do zasady obowiązującej przy opóźnieniu w spełnieniu świadczenia pieniężnego w prawie cywilnym, gdzie dłużnik odpowiada, choćby wierzyciel nie poniósł żadnej szkody, a także wtedy, gdy opóźnienie było następstwem

\footnotetext{
28 Art. 24 ust 1 a usus.

${ }^{29}$ Art. 98 ust 1 pkt 1 a usus.

30 Art. 24 ust 2 usus.

31 Art. 26 ust 2 usus.
} 
okoliczności, za które dłużnik nie ponosi odpowiedzialności (por. art. 481 par 1 Kodeksu cywilnego) ${ }^{32}$.

\section{Postępowanie przed organami mające na celu określenie, kto jest płatnikiem}

Zauważyć należy, że w przypadku zaprzestania opłacania składek przez podmiot przejmujący pracowników (lub też, gdy podmiot ten działał z góry zamierzonym celem nieregulowania zobowiązań), Organy pozostają w uprzywilejowanej sytuacji, gdyż w zależności od sytuacji finansowej stron porozumienia o przekazaniu, mogą próbować udowodnić, że obowiązki płatnicze obciążają dowolny podmiot. Na etapie postępowania zazwyczaj podmiot przejmujący już nie prowadzi działalności, zdążył wyzbyć się majątku, pracowników przekazać kolejnemu podmiotowi. W takim przypadku, organy wydają decyzję, na mocy której uznają, że nie doszło do przejęcia pracowników na mocy art. 23^1 Kodeksu pracy, a więc nie doszło do zmiany pracodawcy, tym samym płatnika składek i organy upoważnione są do dochodzenia należności $\mathrm{z}$ tytułu nieuregulowanych składek od pracodawcy macierzystego, który w dominującej większości przypadków znajduje się w lepszej kondycji finansowej niż podmiot przejmujący (który, jak już zostało wspomniane, niejednokrotnie działał z zamiarem dokonania oszustwa, usypiając czujność organów i kontrahenta, a następnie inkasując kolejne kwoty wynikające $\mathrm{z}$ wystawianych faktur, nie odprowadzał należności składkowych).

Do grupy czynników wzmagających czujność organów należy przede wszystkim „zakres faktycznych obowiązków” podmiotu przejmującego. W decyzjach organy wskazują, że powinności przedsiębiorstwa przejmującego ograniczone były tylko do pośredniczenia w opłacaniu pracowników, na podstawie wcześniej przekazanych środków od byłego pracodawcy, co

\footnotetext{
32 Sprawy z zakresu ubezpieczeń społecznych, pojęcie oraz właściwość postępowań przedsądowych i ochrony cywilnosądowej, Kamil Antonów, Lex a Wolters Kluwers business, Warszawa 2011 r., s 82
} 
jest niewystarczającym by uznać, iż doszło do przekazania zakładu pracy, a więc tytułu pracodawcy, a co za tym idzie - funkcji płatnika składek. Często zwracają również uwagę na moment dokonywania płatności za usługę udostępnienia pracowników. Podejrzenia organów wzbudza sytuacja, w której płatność przez nowego pracodawcę pracownikom następuje krótko po opłaceniu przez pracodawcę użytkownika faktury otrzymanej od przejmującego przedsiębiorcy. Organy wówczas podnoszą, że umowa posiada znamiona pozornej, a jej jedynym przejawem jest zobligowanie innego podmiotu do pośredniczenia w wypłacaniu wynagrodzeń pracownikom.

Niekorzystne dla pracodawcy macierzystego odpowiedzi na powyższe pytania (czyli przyznające znaczącą decyzyjność dotychczasowemu pracodawcy) skutkują stwierdzeniem w orzecznictwie, iż zaistniały sytuacje budzące wątpliwości, kto jest pracodawcą. Wówczas judykatura zwykle powołuje się na regułę, by $\mathrm{w}$ razie wątpliwości w kwestii odpowiedzi na pytanie, kto jest pracodawcą, decydujące znaczenie przypisać faktowi, na czyją rzecz świadczona jest praca. Wątpliwości może budzić podobne rozumowanie $\mathrm{w}$ przypadku, gdy podmiot przejmujący działa w charakterze agencji pracy tymczasowej ${ }^{33}$.

W dalszej kolejności organy prowadzące postępowanie wskazują na takie okoliczności, jak: brak jakiegokolwiek spotkania pracowników przejmowanych z nowym pracodawcą ${ }^{34}$ (dowodzone zeznaniami pracowników), próby wykazania, że to były pracodawca w dalszym ciągu oblicza wysokość wynagrodzenia, a także, że z nim pracownicy ustalają szczegóły urlopów, że nie doszło do rzeczywistej zmiany miejsca świadczenia pracy „przekazywanych” pracowników. Wskazać w tym miejscu należy jednak, że wspomniane powyżej kompetencje mogą pozostawać w gestii dotychczasowego pracodawcy - gdy podmiot przejmujący jest jednocześnie agencją pracy tymczasowej - podmiot przekazujący staje się pracodawcą użytkow-

\footnotetext{
33 Działalność regulowana.

34 Wskazać należy, że $\mathrm{w}$ dominującej większości przypadków, podmiotu przejmujące informują pisemnie swoich nowych pracowników o przejęciu, czyniąc tym samym zadość przepisom prawa pracy.
} 
nikiem i wywiera znaczący wpływ decyzyjny na faktyczny wymiar stosunków pracowniczych ${ }^{35}$. Polemika w tych kwestiach przenosi się zazwyczaj do sądu Okręgowego Wydziału Pracy i Ubezpieczeń Społecznych, właściwego dla strony odwołującej w drodze odwołania wnoszonego na podstawie art. 83 ust 2 usus.

\section{Negatywne konsekwencje}

Bardzo istotną kwestią, z jaką wiążą się nieprawidłowości w zakresie usług outsourcingowych $\mathrm{w}$ dziedzinach pracowniczych, są nie tylko negatywne konsekwencje na tle odpowiedzialności finansowej „macierzystego" pracodawcy, lecz także skutki dla pracowników. To zagadnienie należy jednak rozpatrywać dwutorowo, dzieląc je ze względu na świadomość konsekwencji z tytułu wadliwego porozumienia przez pracowników lub też jej brak. Gdy pracownicy bowiem pozostają nieświadomi komplikacji w zakresie składek na ubezpieczenia społeczne, czyli kwestii, która bezpośrednio ich dotyczy, fakt ten pozostaje bez znaczenia. Jednak dla świadomych jednostek, szczególnie tych wybiegających planami w daleką przyszłość i przejętych dłuższą perspektywą, skutki takie jak utrata poczucia bezpieczeństwa stanowiącego jedną z podstawowych potrzeb w piramidzie Abrahama Maslowa, może nawet skłonić do zmiany pracodawcy. Tym samym, pracodawca musi liczyć się z koniecznością pozyskania i uzupełniania wykwalifikowanej kadry pracowniczej, co w krótkiej perspektywie może być problematyczne.

Negatywne konsekwencje narastają również, gdy pierwsze przesłanki trafiają do środowiska biznesowego pracodawcy. Kontrahenci mogą stać się ostrożniejsi, skrócić terminy płatności zobowiązań, co może zaburzyć płynność finansową przedsiębiorcy, a niektórzy, bardziej wyczuleni na sprawy pracownicze - wprost mogą zrezygnować ze współpracy z pracodawcą „nierzetelnym” w zakresie pracowniczych rozliczeń.

\footnotetext{
35 Ustawa z dnia 9 lipca 2003 r. o zatrudnianiu pracowników tymczasowych (tj. z dnia 29 lutego 2016 r. Dz.U. z 2016 r. poz. 360)
} 
Kolejną grupą negatywnych skutków, niezaprzeczalnie mogących prowadzić do wskazanych wyżej konsekwencji są z pozoru błahe i nie cechujące się zauważalnymi natychmiastowo negatywnymi rezultatami, takie jak: utrata dobrego imienia pracodawcy, pogorszenie wizerunku przedsiębiorstwa, czy utrata wiarygodności.

\section{Podsumowanie}

Wraz $\mathrm{z}$ postępującymi zmianami $\mathrm{w}$ gospodarce, przedsiębiorstwa chcąc dostosować się do dynamicznych realiów gospodarczych coraz częściej decydują się na wybór strategii zarządzania, jaką jest outsourcing. Ze względu na niezaprzeczalne korzyści płynące z fragmentacji przedsiębiorstwa i przekazywania niektórych kompetencji innym podmiotom, działalność outsourcingowa zwiększa swój zakres oddziaływania i w praktyce możliwym stało się przekazanie prawie każdego zadania do realizacji innemu podmiotowi. Dotyczy to również przekazania pracowników wraz z ich dokumentacją kadrową i płacową a także pozyskiwanie pracowników z obcych źródeł bez ponoszenia kosztów rekrutacji. Jak zostało wykazane $\mathrm{w}$ niniejszym artykule, rozwiązanie to może być ryzykowne i skutkujące daleko idącymi negatywnymi konsekwencjami, głównie dla macierzystego podmiotu, przekazującego pracowników. Praktyka bowiem wskazuje, że outsourcing w tej dziedzinie pozostaje w kręgach zainteresowań organów, skłonnych kwestionować ważność porozumień będących podstawą przekazania pracowników, w celu dochodzenia zobowiązań składkowych od wypłacalnych podmiotów. Rezultatem skutecznego zakwestionowania umowy jest uznanie, iż nie doszło do przejścia zakładu pracy w rozumieniu art. 23^1 kodeksu pracy, a tym samym zmiany pracodawcy i transferu statusu płatnika. Końcowo więc zdaniem organów, status płatnika pozostał przy podmiocie przekazującym, który przez cały czas trwania porozumienia, nie będąc świadomym oszustwa kontrahenta, nie opłacał składek na ubezpieczenia społeczne i pozostałych należności budżetowych ${ }^{36}$. Dzieje się tak na skutek uznania

36Podmiot ten często nie zdaje sobie sprawy, że kontrahent nie odprowadza należności budżetowych. 
czynności za pozorną, której celem było ominięcie prawa. Oznacza to najczęściej poważne problemy finansowe działającego w zaufaniu do kontrahenta przedsiębiorcy, skutkujące koniecznością egzekucji należności publicznoprawnych, co nierzadko może zaskutkować koniecznością likwidacji działalności przez przedsiębiorcę. Konkludując należy wskazać, że w opisanych powyżej przypadkach, chęć zmiany strategii zarządzania, poprawy wydajności może skutkować ogromnymi problemami finansowymi przedsiębiorcy, które $\mathrm{w}$ skrócie są efektem nieostrożności $\mathrm{w}$ tak podstawowym elemencie prowadzonej działalności, jak obowiązek odprowadzania składek na ubezpieczenia społeczne.

\section{Bibliografia}

1. Antonów Kamil, Sprawy z zakresu ubezpieczeń społecznych, Wolters Kluwers business, Warszawa $2011 \mathrm{r}$.

2. Basińska Joanna, Outsourcing pracowniczy optymalizuje zatrudnienie, Prawo i podatki, czerwiec $2015 \mathrm{r}$.

3. Ciesielska Dorota, Radło Mariusz-Jan, Outsourcing w praktyce, wydawnictwo Poltext, Warszawa $2011 \mathrm{r}$.

4. Kalinowska Karolina, Outsourcing jako metoda zarzqdzania przedsiębiorstwem, Zeszyty naukowe polityki europejskiej, finanse i marketing, Nr 3 (52) 2010,

5. Kosacka Dorota, Olszewski Bogdan, Leksykon świadczeń ZUS, Unimex, Wrocław 2015,

6. Kurzych Andrzej, Multiplikacja podmiotów zatrudniających a stosunki ubezpieczenia społecznego [w:] Marzena Szabłowska - Juckiewicz, Monika Wałachowska, Jacek Wantoch- Rekowski (red.), Umowy cywilnoprawne w ubezpieczeniach społecznych, Warszawa $2015 \mathrm{r}$.

7. Gudowska Beata, Jolanta Strusińska - Żukowska, Komentarz do ustawy o systemie ubezpieczeń społecznych, 2 wydanie, wyd. BECK, Warszawa $2014 \mathrm{r}$.

8. Szczepankiewicz Elżbieta Izabela, Strategiczny wymiar outsourcingu i cosourcingu jako narzędzia optymalizacji procesów wewnętrznych przedsiębiorstwa $i$ budowania przewagi konkurencyjnej [w:] Antonowicz Alicja, Antonowicz Paweł(red.), Metody, techniki i narzędzia optymalizacji procesów gospodarczych, Wydział Zarządzania Uniwersytetu Gdańskiego Fundacja Rozwoju Uniwersytetu Gdańskiego, Sopot 2011 r. 
9. Ustawa z dnia 9 lipca 2003 r. o zatrudnianiu pracowników tymczasowych (tj. z dnia 29 lutego 2016 r. Dz.U. z 2016 r. poz. 360).

10. ustawa z dnia 13 października 1998 r. o systemie ubezpieczeń społecznych (tj. z dnia 7 czerwca 2016 r. Dz.U. z 2016 r. poz. 963). 